\title{
Good Instructional Leadership: Principals' Actions to Increase Composite ACT School Scores
}

\author{
Bo $\mathrm{Xu}^{1} \&$ Dongfang $\mathrm{Liu}^{2}$ \\ ${ }^{1}$ The Higher Education Research Institution, Sichuan International Studies University, Chongqing, China \\ ${ }^{2}$ Educational Leadership and Policy Studies, University of Northern Colorado, Greeley, USA \\ Correspondence: Dongfang Liu, Educational Leadership and Policy Studies, University of Northern Colorado, \\ Greeley, USA. E-mail: dongfang.liu@unco.edu
}

Received: January 20, 2016

Accepted: March 8, $2016 \quad$ Online Published: July 26, 2016

doi:10.5539/ies.v9n8p120

URL: http://dx.doi.org/10.5539/ies.v9n8p120

\begin{abstract}
Due to increased college admission requirements and a 20-year flat-lined trend in ACT scores, it is imperative for education leaders across the nation to implement effective strategies to increase ACT composite scores. High school principals, as instructional leaders and decision makers, are the major stakeholders who are vested in the outcomes of the study. Findings based upon questionnaires can provide a description of the actions that principals report taking to increase composite ACT school scores.
\end{abstract}

Keywords: ACT composite score, principal's role, standardized assessment

\section{Introduction}

\subsection{Introduction of the Problem}

ACT reports that the national average composite score in 1994 was 20.8, in 2004 it was 20.9, and nearly 20 years later, in 2014, the score was 21 (ACT, 2014d). As national ACT composite scores have remained unchanged over 20 years, evidence from a review of universities' admission standards indicate a rise in ACT composite score standards (University of Colorado at Boulder, 2014; University of Colorado at Colorado Spring, 2014; University of Colorado at Denver, 2014).

The ACT is a tool used throughout the country by students, high schools, and colleges (ACT, 2014g). According to ACT (2014g), high school students demonstrate a command of information taught over the period of their high school academic journey. For many students, in order to continue on an education journey an admissions test is required, such as the ACT, to be accepted into a college (ACT, 2014f). Students' admission scores are important, as it determines where students are able to go to college and what classes students should take (ACT, 2014f).

Many high schools use ACT scores to help evaluate effective instruction, identify students who need assistance and guidance, and plan changes in improvements in curriculum such as college preparation programs (ACT, 2014g). Colleges use ACT scores for recruiting students, advising students, course placements, scholarships, and retention. The United States of America is a nation that desires an education system that cultivates competent college and career ready students (ACT, 2014a).

The focus of this study is to explore actions principals report taking to increase composite ACT high school scores. Having this understanding could allow high school leaders and educators to purposefully evaluate effective instruction, intentionally provide assistance and guidance for students, and strategically implement efficacious results oriented ACT preparation programs (ACT, 2014g). The researchers present the current problems of increased college entrance requirements and intensified high school accountability in the following sections.

\subsection{Importance of the Study}

Adams (2014) was quoted to say, "For 2012 graduates, the average score was 21.1. Scores have hovered right around 21 over the past decade; in 2004 the figure was 20.9" (Adams, 2014, p. 1). Adams (2014) also cited Robert Rothman, a senior fellow at the Alliance for Excellent Education, that "High school performance has been flat for more than a decade" (Adams, 2014, p. 1). According to the Minnesota Office of Higher Education 
(MOHE) national ACT composite scores from 2005 to 2014 were around 21, while Minnesota obtained the highest scores of all states ranging from 22 to 23 (MOHE, 2014). Additionally, Colorado, which is the focus of this study, obtained an average composite score of 20.4 in 2013 (MOHE).

Meanwhile, the admission standards pertaining to ACT scores have increased. Massachusetts Institute of Technology's (MIT) Common Data Set revealed that from 2003 to 2014, its admission standard pertaining to ACT scores rose from $84 \%$ of ACT composite range of $30-36$ to $94.2 \%$ of ACT composite range of 30-36 (Massachusetts Institute of Technology [MIT], 2014). Also, based on University of California at Los Angeles (UCLA) profile of admitted freshmen, the difference in the data is even more significant. In 2013, 38.23\% of UCLA applicants' ACT English score ranged from 30 and above. In 2003, 22.73\% of UCLA applicants' ACT English score ranged from 30 and above (University of California at Los Angeles [UCLA], 2014).

The instances above are not isolated examples. It is easy to find similar reports from many major universities in America. ACT scores are not the only indicators used in the admission selection process, but the importance of ACT scores in a high school student's college application cannot be overlooked (University of Colorado at Boulder, 2014; University of Colorado at Colorado Spring, 2014; University of Colorado at Denver, 2014).

MIT (2014) and UCLA (2014) reported increasing undergraduate applicants during the last decade, while the two schools' numbers of acceptance remained at the same level for the last ten years. This is evidence that applying for colleges/universities has become incrementally competitive. Aside from those nationally recognized prestigious schools, regular state higher education institutions have consistently increased their standards of admissions. For instance, profiles from the University of Colorado University System revealed evidence that state colleges/universities currently expect higher standardized test scores in the application due to the increasing number of applicants for undergraduate admissions. With a stable enrollment population for the University of Colorado University System, the freshmen applicants have soared between 2000 and 2010 (UCB, 2014, UCD, 2014; UCCP, 2014).

The information presented above is an example of flat-lined ACT composite scores and an increase in ACT admission requirements. Additionally, the ACT examination is an important test for Colorado high schools due to its inclusion in school accreditation ratings and publication of a high school composite score (Colorado Department of Education, 2014). The primary role of the principal is to sustain and create an academic environment that maximizes teachers' ability to teach and students' ability to learn (Adams, 1999). In this regard, it is important for researchers to understand and explore the principal's impact in promoting a high ACT composite school score.

\subsection{Relevant Literature}

Shifts in educational requirements have led to a transformation of the role of the principal (Rigby, 2014). For instance, the work from Louis, Leithwood, Wahlstrom, and Anderson (2010) argued that twenty-first century principals are required not only to fulfill building level administrator duties but also now must be an instructional leader. Throughout the history of education, society has held a notion that the main role of a principal is to help students obtain school success (Louis, Leithwood, Wahlstrom, \& Anderson, 2010). Boyd et al. (2011) stated one of the rationales for this study was to explore principals' impact in schools to increase academic excellence, specifically, with the ACT scores (Boyd et al., 2011).

Past research on education administration explored multiple strategies used by principals to increase student performance. The research illuminated strategies used in the school environment that are contributing factors for how principals successfully implement their roles and take action (Coburn, 2005; Daly, Moolenaar, Bolivar, \& Burke, 2010; Spillane, Parise, \& Sherer, 2011). As Coburn (2005) stressed, principals need to create a collaborative, clear mission and vision focused on academic excellence in order to increase student achievement. It is important to increase efficacy by ensuring educators have a clear understanding of how to implement the standards (Coburn, 2005). In addition, the definition of a principal's role and work within a school is to provide a map of the contextual information in which principals, principal preparation programs, school districts, and other principal support programs produce effective outcomes (Daly et al., 2010). Both practitioners and researchers can use these strategies as a method to direct actions of reform and support educators (Spillane, Parise, \& Sherer, 2011).

Current research focused on the principals' actions as instructional leaders that influence academic outcomes (Rigby, 2014). A group of recent researchers argued that, next to teaching, school leadership is a key component to educational success in school (Bryk, Sebring, Allensworth, Luppescu, \& Easton, 2010; Hallinger \& Heck, 1998; Leithwood, Louis, Anderson, \& Wahlstrom, 2004; Supovitz, Sirinides, \& May, 2010; Waters, Marzano, \& McNulty, 2003). Additionally, the literature from Leithwood et al. (2004) and Louis et al. (2010) addressed that 
school leaders play a critical role in developing and sustaining effective academic operations in schools. Understanding the roles in which principals are expected to fulfill is essential for both researchers in the education field and practitioners, principal preparation programs and school district leadership. All strategies working together toward a common vision and mission of academic excellence will result in increased student achievement (Waters, Marzano, \& McNulty, 2003). Researchers of this study fill a gap in the literature by explaining the specific expectation of principals' impacts in improving students' ACT performance. The researchers of this study provide a framework on which future research can rely, as well as, a scaffold for practitioners to frame their training and support work for school leaders.

\section{Method}

In seeking to delve the research problem, it is important to understand the context and meaning through an epistemological lens. Crotty (1998) states epistemology is "how we know what we know" (p. 8). To ensure legitimacy through philosophical grounding the researchers used a subjective epistemology. According to Crotty (1998), subjectivism occurs when the meaning comes from the subject, which is then imposed on the object. Using survey response data, the researchers coded principals' statements regarding the actions taken to increase composite ACT high school scores.

In interpreting meaning from the subject, researchers must be aware of biases and assumptions, identified by Crotty (1998) as a theoretical perspective. Cognizant of the biases and assumptions in this study, the researchers identified interpretivism as the form of theoretical perspective. This is due in part to the historical lens from which the researchers will draw from for the participant's responses. More specifically, the researchers in this project are studying from the perspective of the participants, identified by Crotty as a phenomenological perspective. The researchers in this project are interested in the principal's perspective of actions taken to increase high school composite ACT school scores.

In order to ensure the subjective nature of the participant's responses are not prejudiced, the researchers gathered data by way of unstructured, open-ended questionnaires. Through the use of open-ended questionnaires, the researchers were able to specifically identify the data without imposing themes on the participants. This approach falls in line with Crotty's (1998) description of phenomenological methodology.

\subsection{Sampling and Data Collection Procedures}

The sample consisted of high school principals from Colorado school districts. School districts were purposefully selected based on the criteria that the target high schools have a variety of economic, ethnic, and special student populations. The researchers obtained permission to conduct research within these school districts and contacted all high school principals in the district by email to explain the purpose of the study as well as seek participation. A letter of consent was emailed to each prospective participant. Researchers collected and obtained signed consent forms from willing participants. The signed letters were scanned and emailed back to the researchers. Data in this study was collected through an electronic questionnaire. Each survey questionnaire was emailed to respective principals to complete. Principals wrote their responses to the questionnaire and submitted them to the researchers electronically. Data collected was analyzed in order to identify specific themes.

\subsection{Analysis Procedures}

Following the IRB protocol, the researchers transcribed participants' responses into a spreadsheet with no identification attached to protect confidentiality. The process of analysis was iterative and involved both deductive and inductive strategies (Creswell, 1998). Once preliminary descriptions and themes were constructed, the researchers re-approached selected participants to validate if the themes were their original ideas. Member checking crossed locations and campuses. The results indicated a high level of consistency in participants' perceptions from different school types. If new relevant themes occurred from the second-time visit to participants, then they were also included in the final description. In the end, from 34 verbatim transcripts, 228 significant statements and phrases were recognized and extracted and arranged into the formulated meanings. Then, the researchers clustered the formulated meanings into themes.

In this study, methodological rigor was attained through the application of verification, validation, and validity (Meadows \& Morse, 2001). Verification is the first step in achieving validity of a research project. Using the protocols from Frankel (1999) and Meadows and Morse (2001), verification of this study was fulfilled through a review of existing relevant literature, strict adherence to the phenomenological method, bracketing of past experiences, proper documentation of observations and field notes, collection of appropriate data samples, identification of negative cases, and saturation of interview data. Validation of the study was within-project 
evaluation and was accomplished by multiple methods of data collection (questionnaires and document analysis), data analysis and coding by member checks of the participants. The various steps of the study helped to create multiple viewpoints on the topic across issues relating to leadership's actions to increase composite ACT school scores.

\section{Results}

The researchers distributed questionnaires to 48 principals that included six questions in order to identify actions principals reported taking to increase composite ACT high school scores. The researchers obtained 34 responses back from the high school principals. The researchers identified 37 meaningful action statements from what principals reported doing to improve composite ACT high school scores. The researchers used the meaningful statements to identify common themes among the principals' responses.

The identified themes were a report of what principals stated they did in order to improve composite ACT high school scores. In order to be considered a theme, the principals' responses needed to occur on at least two of the questionnaires. In the following sections, the researchers dove deeper and examined what themes evolved from the principals' responses on actions taken to improve composite ACT high school scores. Three specific themes were identified that principals reported taking: (a) training programs, (b) staff professional development, and (c) communication.

\subsection{Training Programs}

Principals in all 34 schools reported a variety of programs that were enacted under their leadership. Three training programs were specifically identified for students to utilize in order to improve their scores. Furthermore, by individual students collectively improving their respective ACT scores, composite ACT high school scores also improved. The three training programs utilized by building level administrators were ACT practice tests, ACT review sessions, and the use of an online training program called Shmoop.

Building level leaders from all 34 high schools reported using ACT practice as one way to improve composite ACT school scores. The amount of time and frequency the practice was conducted varied by school, but a common theme was the use of ACT practice exams. The principal from high school A reported an emphasis had been made to "infuse ACT practice questions into our daily warm ups for students in 11th grade English and math courses." Additionally, the school gave students in $9^{\text {th }}, 10^{\text {th }}$, and $11^{\text {th }}$ grades ACT practice tests in order to prepare students for the ACT. The principal from high school D also reported a focus on preparing students early for the ACT through the use of practice assessments for $9^{\text {th }}, 10^{\text {th }}$, and $11^{\text {th }}$ grades. "Beginning in 2005 when I started as principal we started giving the PLAN to all sophomore students in the fall." The principal then continued by reporting "in 2007 we added the Explore and gave this exam to our freshmen." The use of ACT practice tests was common by all schools, but only schools A and D reported using ACT practice tests in multiple grade levels. The remaining principals in the study reported giving an ACT practice test one time per year to the junior class.

Another action reported commonly by the principals in this study was the use of ACT review sessions in order to better prepare students for the assessment. The principal from high school C conveyed, "the learning center then provided a series of ACT preparation classes that students could pay for and take." The number of review sessions provided varied by school. The principal at school F reported the school provided two sessions each consisting of two hours in length. Additionally, school X "also does a school-wide ACT prep class on April $1^{\text {st }}$ for all juniors." School E's principal reported offering "a four day test prep during state testing window for all juniors, focusing on ACT skills in Reading, Math, Science and English." Similarly high school E offers a 12-week test prep leading up to the ACT, of which 70 students participated in spending two and a half hours per week. This was the most time any principal reported spending on ACT review sessions.

The final action commonly reported by building level leaders was the use of Shmoop, an online company that provides a variety of resources for teachers, administrators, and students. Eleven principals reported using this tool. While the principals reported using Shmoop as a resource, there was no detailed information provided explaining the benefit of the resource or how the site was implemented in the schools to improve composite ACT high school scores.

\subsection{Staff Professional Development}

A second theme the researchers identified was professional development for high school staff to improve composite ACT high school scores. The principals at schools A, B, C, D, E, F, G, H, I, J and M reported providing staff professional development for ACT preparation. The principals at school B, C, G, H I, J, K, L, O, $\mathrm{P}, \mathrm{R}, \mathrm{Y}$ and $\mathrm{Z}$ led the staff through data analysis of ACT scores. "We compared our scores with scores from other 
high schools with similar SES", stated the principal from high school B. This was a staff-wide effort to analyze performance for their respective school. Additionally, the most of principals who participated in the study reported that providing support and professional development for staff on the use of Shmoop were beneficial to students' ACT scores improvement.

The principal at high school D also believed staff professional development to be an important action taken to improve composite ACT scores. "I attended the ACT conference every year and picked up different strategies to share with staff through PD" stated the principal at school D. The principal continued by expressing the importance of educating the staff at the school. "One of the major moves I feel that I made was educating the staff on the ACT. What the scores were used for, what the college readiness standards meant, what the benchmark scores mean."

\subsection{Communication to Stakeholders}

The final theme the researchers identified that principals reported doing was communicating to key stakeholders. All principals reported communication was something they had done. The principal from school A stated communication occurred by "meetings set-up with stakeholders to get around the table and explore strategies related to improving ACT test scores." The principal from school $\mathrm{S}$ emphasized the importance of communication with key stakeholders. "We have increased communication and discussion among our students, teachers, and parents." This principal believed this increased communication has had a direct impact on the success the school has seen on the school's composite ACT school score. "I believe this has heightened awareness and has contributed to better buy-in and more seriousness about preparing for the ACT. This is a qualitative improvement."

Additional actions were also reported by the principals of this school district and are worth mentioning. Twenty-nine principals believed an emphasis on improving instructional strategies and building relationships with students was an important action that was taken. The principal of high school $\mathrm{K}$ reported building level leadership identified students with a high grade point average and low test score on the practice ACT. "Each of our administrators has taken on 6 students for check-in and tutoring on ACT. These are our target students." The principal at school E reported the action of hiring appropriate personnel as being important. "Also I've had a huge impact in hiring a teacher with previous experience with Huntington Learning Centers, who provides our ACT tutorial. Many staff now has ACT awareness in their content area having taught the prep session."

\section{Discussion}

In this study, the gleaned responses evinced the actions that principals have employed to help students obtain school success. The responses mirrored the findings of Hollingworth, Dude, and Shepherd (2010) that building level administrators, facing the pressures of high-stakes testing, have been forced to look beyond classroom instruction when looking to improve achievement on standardized assessment. Researchers identified the variables inside schools that impact students' ACT performance.

Inside the school environment, themes identified from principals' responses indicated a lack of teacher focus for ACT preparatory programs and curriculum alignment with the ACT inhibited improvement on ACT school composite scores. The findings from the study substantiated the importance of preparatory programs and curriculum in the ACT preparation, and resonated the previous study from Shaver (2013) that curriculum that contains test-taking strategies has shown to be effective, and from Kretlow, Lo, White, and Jordan (2008) that teaching test-taking strategies that focus on training on test formats, reasoning and deduction, time management, practice exams, and coaching can improve achievement on standardized assessments for all students.

Inquiring about principals' actions attributing to high school students' ACT scores, the researchers identified common actions that are believed to be an effective method to improve high school students' ACT performance. Current high school principals developed these actions. Based on the principals' responses, meaningful statements pertaining to their action on promoting students' ACT scores emerged and clustered into themes. Those themes can offer a scaffold for practitioners to frame their training and support work for school leaders. Three specific themes were identified that principals reported taking: (a) training programs, (b) staff professional development, and (c) communication.

Three training programs were specifically identified for students to utilize in order to improve their scores. By individual students collectively improving their respective ACT scores, composite ACT high school scores also improve. The three training programs utilized by building level administrators were ACT practice tests, ACT review sessions, and the use of an online training program called Shmoop.

Staff professional development is reported to improve composite ACT high school scores. Some principals in the 
study reported providing staff professional development for ACT preparation, because the principal believed staff professional development was an important action taken to improve composite ACT scores. The other principals continued by expressing the importance of educating the staff at the school in order to help students achieve high ACT scores.

Finally, communicating to key stakeholders is beneficial and helpful for improving ACT scores. Emphasizing the importance of communication with key stakeholders, some principals believe this increased communication has had a direct impact on the success the school has seen on the school's composite ACT school score. Additionally, some participants believed an emphasis on improving instructional strategies and building relationships with students was an important action that was taken. For instance, building level leadership identified students with a high grade point average and low-test score on the practice ACT.

\section{Acknowledgments}

The authors would like to give special thanks for the support of the Higher Education Research Institution, Sichuan International Studies University.

\section{References}

ACT. (2014a). Retrieved from http://www.act.org/aboutact/history.html

ACT. (2014b). Retrieved from http://www.act.org/aboutact/whoweserve.html

ACT. (2014c). Retrieved from http://www.act.org/collegechoice/13/

ACT. (2014d). Retrieved from: http://www.act.org/newsroom/data/2014/states.html

ACT. (2014e). Retrieved from http://www.actstudent.org/college/applying

ACT. (2014f). Retrieved from http://www.actstudent.org/college/plancourses.html

ACT. (2014g). Retrieved from http://www.actstudent.org/scores/understand/howused.html

Adams, C. (2014). ACT Scores Virtually Unchanged; Participation Up. Education Week, 34(2), 8.

Adams, J. P. (1999). Good principals, good schools. Educational Leadership, 29(1), 8-11.

Boyd, D., Grossman, P., Ing, M., Lankford, H., Loeb, S., \& Wyckoff, J. (2011). The influence of school administrators on teacher retention decisions. American Educational Research Journal, 48, 303-333. http://dx.doi.org/10.3102/0002831210380788

Bryk, A. S., Sebring, P. B., Allensworth, E., Luppescu, S., \& Easton, J. (2010). Organizing schools for improvement: Lessons from Chicago. Chicago, IL: University of Chicago Press.

Coburn, C. E. (2005). Shaping teacher sense making: School leaders and the enactment of reading policy. Educational Policy, 19, 476-509. http://dx.doi.org/10.1177/0895904805276143

Colorado Department of Education. (2014). District accountability handbook (Version 4.1). Retrieved from http://www.cde.state.co.us/accountability/district_accountability_handbook2014

Creswell, J. (1998). Qualitative inquiry and research design: Choosing among five traditions. Thousand Oaks, CA: Sage.

Daly, A. J., Moolenaar, N. M., Bolivar, J. M., \& Burke, P. H. (2010). Relationships in reform: The role of teachers' social networks. Journal of Educational Administration, 48, 359-391. http://dx.doi.org/10.1108/09578231011041062

Frankel, R. M. (1999). Standards of qualitative research. In B. F. Crabtree, \& W. L., Miller (Eds.), Doing qualitative research (2nd ed., pp. 333-346). Thousand Oaks, CA: Sage.

Hallinger, P., \& Heck, R. H. (1998). Exploring the principal's contribution to school effectiveness: 1980-1995. School Effectiveness and School Improvement, 9, 157-191. http://dx.doi.org/10.1080/0924345980090203

Hollingworth, L., Dude, D. J., \& Shepherd, J. K. (2010). Pizza parties, pep rallies, and practice tests: Strategies used by high school principals to raise percent proficient. Leadership and Policy in Schools, 9(4), 462-478. http://dx.doi.org/10.1080/15700760903342376

Kretlow, A. G., Lo, Y., White, R. B., \& Jordan, L. (2008). Teaching test-taking strategies to improve the academic achievement of students with mild mental disabilities. Education and Training in Developmental Disabilities, 43(3), 397-408

Leithwood, K., Louis, K. S., Anderson, S., \& Wahlstrom, K. (2004). How leader- ship influences student 
learning: Executive summary. Minneapolis: University of Minnesota Center for Applied Research and Educational Improvement.

Louis, K. S., Leithwood, K., Wahlstrom, K. L., \& Anderson, S. E. (2010). Investigating the links to improved student learning: Final report of research findings Learning from Leadership Project. St. Paul: University of Minnesota: Center for Applied Research and Educational Improvement.

Meadows, L. M., \& Morse, J. M. (2001). Constructing evidence within the qualitative project. In J. M. Morse, J. M. Swansen, \& A. Kuzel (Eds.), Nature of qualitative evidence (pp. 187-200). Thousand Oaks, CA: Sage.

Minnesota Office of Higher Education. (2014). ACT \& SAT test scores [Web Blog post]. Retrieved from http://www.ohe.state.mn.us/fc/792/pg.cfm

MIT. (2014). Common data set [Web Blog post]. Retrieved from http://web.mit.edu/ir/cds/index.html

Rigby, J. G. (2014). Three logics of instructional leadership. Educational Administration Quarterly, 50(4), 610-644. http://dx.doi.org/10.1177/0013161X13509379

Shaver, W. (2013). Effects of remediation on high-stakes standardized testing. (Order No. 3537545, Yeshiva University). ProQuest Dissertations and Theses, 97. Retrieved from http://0-search.proquest.com.source.unco.edu/docview/1322974476?accountid=12832

Spillane, J. P., Parise, L. M., \& Sherer, J. Z. (2011). Organizational routines as coupling mechanisms: Policy, school administration, and the technical core. American Educational Research Journal, 48, 586-619. http://dx.doi.org/10.3102/0002831210385102

Supovitz, J., Sirinides, P., \& May, H. (2010). How principals and peers influence teaching and learning. Educational Administration Quarterly, 46, 31-56. http://dx.doi.org/10.1177/1094670509353043

University of California at Los Angeles. (2014). Profile of admitted freshmen fall 2013 [Web Blog post]. Retrieved from http://www.admissions.ucla.edu/Prospect/Adm_fr/Frosh_Prof.htm

University of Colorado at Boulder. (2014). Profile of admitted freshmen [Web Blog post]. Retrieved from http://www.admissions.ucb.edu/Prospect/Adm_fr/Frosh_Prof.htm

University of Colorado at Colorado Spring. (2014). Profile of admitted freshmen [Web Blog post]. Retrieved from http://www.admissions.uccs.edu/Prospect/Adm_fr/Frosh_Prof.htm

University of Colorado at Denver. (2014). Profile of admitted freshmen [Web Blog post]. Retrieved from http://www.admissions.ucd.edu/Prospect/Adm_fr/Frosh_Prof.htm

Waters, T., Marzano, R. J., \& McNulty, B. (2003). Balanced leadership: What 30 years of research tells us about the effect of leadership on student achievement. Aurora, CO: Mid-Continent Research for Education and Learning.

\section{Copyrights}

Copyright for this article is retained by the author(s), with first publication rights granted to the journal.

This is an open-access article distributed under the terms and conditions of the Creative Commons Attribution license (http://creativecommons.org/licenses/by/4.0/). 